\title{
GROWTH ORIENTATION OF WOMEN AND MEN OWNERS OF MICRO FIRMS IN THE POMERANIAN REGION
}

\author{
Julita E. Wasilczuk*
}

\begin{abstract}
Background. Despite the fact that research on women's entrepreneurship has been conducted for many years, still many clear answers to questions about the differences between entrepreneurs of both genders are missing. One of the unresolved issues is the performance of women in entrepreneurship.

Research aims. The aim of the study is to investigate the growth orientation of microenterprises operating in the Pomeranian region in Poland and to compare its level according to the gender of the owner.

Methodology. An index of entrepreneurs' growth orientation was developed. This index, being a determinant of the company's growth potential, was based on five indicators: goals and plans of the entrepreneur, innovative activities, investment, and activity in finding sources of funding. The data was gathered by a face to face survey, based on a questionnaire, among microfirm owners from the Pomeranian region - Poland, in 2009 and 2012.
\end{abstract}

Key findings. The analysis of growth orientation of women and men, pointed out that the first showed a lower indicator of it, however again the general conclusions are not so clear.

Keywords: women entrepreneurship, growth orientation.

\section{INTRODUCTION}

The first report on women's entrepreneurship, the aim of which was to draw attention to the barriers they may experience, was a result of an initiative of the President of the United States in 1979. It relied to a large extent on data collected since 1972 within the framework

* Gdańsk University of Technology. E-mail: jwas@zie.pg.gda.pl 
of the Survey of Business Owners (Survey of Business Owners, 2016) programme. The report revealed that statistically, women running companies were over forty years old, earned a third of what men running companies made and were owners of companies operating in the white collar in the retail and service sector (United States Department of Commerce, 1979). The authors of the report were surprised by the fact that the rate of increase in the number of women's businesses was three times faster than in the case of companies run by men. Women established their companies after several years of practice in the market and their business profile was associated with such practice, as opposed to education. The female entrepreneurs were mainly college ( $46 \%$, however not in the field of management) and high school graduates (22\%) (United States Department of Commerce, 1979). The Polish readers of the report may be surprised by the information on financing the start-up phase of the enterprises: $31 \%$ of respondents received funds from banks or government institutions. In the Polish reality, the entrepreneurs even now, regardless of gender, cannot count on such a large share of institutional financing of the start-up stage. $65 \%$ of women applied for bank loans for further operation of their businesses, although, as the report authors point out, the banks perceived them as less creditworthy borrowers.

The report cited above and the first articles, conference presentations, and books concerning the issue of women's entrepreneurship appeared only in the late 1970s and early 1980s, although the first research on entrepreneurship itself began in the 1940s and 1950s, when the Harvard Business School started to publish its Explorations in Entrepreneurial History (Jones \& Wadhwani, 2006) magazine. Jennings and Brush (2013) believe that there may be three reasons for this belated interest in women's issues. Firstly, women were not seen as a distinct group of business owners. Secondly, business women were rarely exposed in the media, which also resulted in lower interest of the academia. The last of the raised arguments related to the perception of entrepreneurs as a homogeneous group - regardless of gender. This argument returns nowadays, i.a. in (Ahl, 2006). Also, this list should certainly be interpreted in light of the fact that the participation of women in the economy was underestimated at that time in general.

Polish entrepreneurial reality in this period did not exist, neither for men, nor for women. The artisan businesses or so-called home-based 
work were not reported, and the more so no-one dealt with the entrepreneurship of women.

The history of research on women's entrepreneurship in relation to the history of research on entrepreneurship in general is shown in Figure 1.

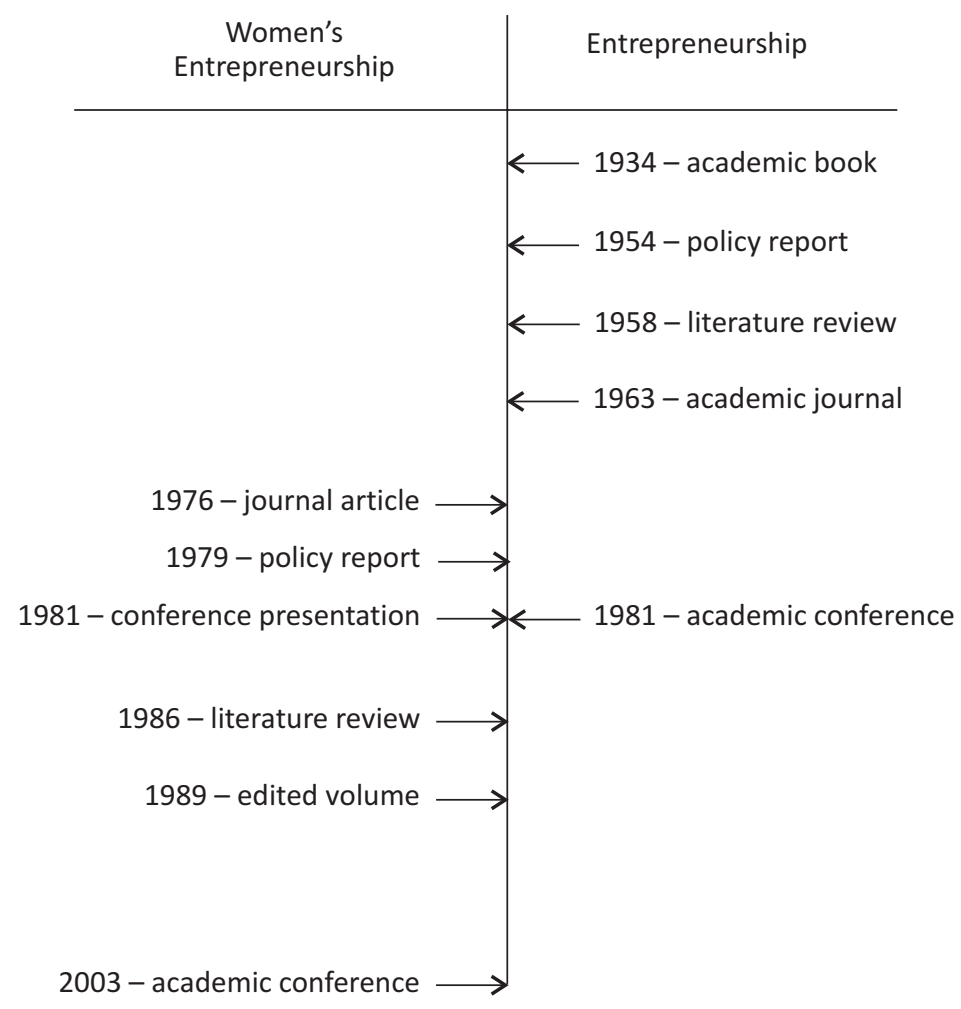

Figure 1. Milestones in women's and general entrepreneurship research in world.

Source: based on Jennings \& Brush, 2013.

It might be worthy to show in the presented diagram some milestones in research on women's entrepreneurship in Poland. The group of Polish researchers dealing with this issue is growing (see e.g. Horodyńska-Okoń, Kupczyk, Lisowska, Misiak, Siemieniak Wasilczuk, and Zięba).

When analysing the literature on functioning of businesses and entrepreneurs, regardless of gender, there is no answer to many questions, mainly in the field of performance. The number of unanswered 
questions is growing when it comes to literature on entrepreneurs of different genders, and therefore there is a need for research in this area.

\section{THEORETICAL FRAMEWORK}

Many reports in the literature point to the underperformance of women in business, in comparison with men. It is related to:

- lower level of engagement in entrepreneurial activity (Kelley et al., 2016);

- differences in chosen strategies (Jennings \& Brush, 2013);

- employee headcount and sales volume (Sabarwal \& Terrell, 2008) and the size of capital (Muravyev et al., 2009).

It is worth stressing, however, that the results of the research are not unambiguous - the newest sources, citing more studies, are listed above.

Reading the reports on the differing results achieved by businesses run by male and female owners leads to questions about their causes. They can be due to various barriers faced by male and female entrepreneurs - conditioned both by family situation (the need to provide care for children/parents) and by discrimination issues. However, they may also be a result of a variety of personal choices, stemming from different expectations and goals that men and women set for themselves while establishing and running businesses. Both of the above approaches - the one based on barriers and the one suggesting a different attitude towards business activity - can be found in feminist theories. The first is embedded in liberal feminism, which is based on the assumption that men and women do not differ, but the former are discriminated against and face additional barriers. They achieve less than men because they have worse educational and professional opportunities (Fischer et al., 1993). Moreover, they are discriminated against i.a. in the credit market (Marlow \& Patton, 2007), although recent studies have not confirmed this unequivocally (Calcagnini et al., 2015). The second approach is related to socialist feminism and points to differences between the sexes: both in terms of needs or experiences and in terms of competencies and values (Poggesi et al., 2015). According to socialist feminism, these differences are a result of different educational and historical heritage, which makes women cope worse because of a lack of confidence or faith in self-efficacy. This 
often results in a lack of motivation to seek e.g. external financing of their business activity (Calcagnini et al., 2015). Women take different attitudes than men, which also causes the model of their companies to differ (Lee \& Marvel, 2014) - they start with less capital, both financial and human, and are engaged mainly in services (European Commission, 2016). Often the motivation to start a business stems from the need to combine family responsibilities with paid employment or the lack of other opportunities in the labour market. According to the research of the Entrepreneurship Global Monitor, women are largely driven by negative motives, arising out of necessity, as opposed to desire to set up a business (Kelley et al., 2016). To sum up the discussion of social feminism, it can be said that the subsequent entrepreneurial achievements are shaped to a large extent by these founding decisions (growth, innovation, survival, etc.) (Wasilczuk, 2005).

Regardless of the current of feminist ideology (there are more than those listed above), one aspect relating to women's entrepreneurship is explicitly recognised: women are different than men. The methods of explaining the causes of such state and the relevant remedies is what differentiates the various currents of feminism. As part of the entrepreneurship research, socialist feminism is gaining more and more supporters, as discrimination in the modern world is less and less prevalent - although according to the World Bank Report, many countries still have regulations that discriminate against women, e.g. in Poland there are three such laws (Women, Business, and the Law: Getting to Equal Report, 2016). This puts Poland behind 18 countries where there is not even one such regulation (i.a. Hungary, Slovakia, Spain, Peru, or Taiwan) and some with one or two formal restrictions for women. An easily recognisable area of discrimination, although not resulting from the legislation, is the so-called gender pay gap, which in the case of the hourly wage in Europe amounts to 16.3\% (in Poland only $6.4 \%$ ) and in the case of total gross earnings it reaches $41.1 \%$ (in Poland 29.6\%) (European Commission, 2016).

The emerging picture of the business situation of women points to two groups of factors that affect the potential of their enterprises. On the one hand, women choose activity that is not conducive to the development of the company and introduction of new solutions, e.g. innovations. The businesses from the service sector, operating at the owner's home and financed from savings are not predisposed for increasing the scale of activity. As a result, the consequence of the 
decisions made at the establishment phase is the lower potential of the enterprises. On the other hand, women often consciously resign from making development decisions. This could be due to the fear of failure or low self-esteem, but also a conflict between business objectives and personal goals. These are, however, general observations based on research in this area conducted for many years (Gawrycka et al., 2007). However, recently it can be observed that women begin to act in business like men Ahl (2002), and Wasilczuk (2015) even suggests that the differences between types of women in business are more pronounced than in the case of differences between women and men. As a result, the argument that there is no need to deal with women as a separate research group becomes more significant nowadays. And while citing the research from several years ago, indicating the differences between the genders in business, it has to be kept in mind that they are beginning to lessen which does not mean that they are absent.

From the above analysis of the literature, an incomplete picture of feminine entrepreneurship in the world emerges. Previous reports about the underperformance of women are ambiguous. The researches were conducted in different countries and at a different time. Perhaps that is why their results did not allow answering many questions, including those that concern the performance of women's businesses. It is no wonder that little is known about the entrepreneurial activity of women in Poland, especially since the results of the research conducted in the world cannot be directly transferred to Poland. It is also significant that the cultural context influences entrepreneurial activity (Glinka, 2008). Knowledge about functioning of women in enterprises is drawn mainly from the results of research conducted in countries with a long tradition of entrepreneurial activity - in terms of establishing and running a business. Poland does not belong to such countries, although many activities undertaken during the planned economy can also be included in entrepreneurial activities, like informal services and trade etc., even though they were not formal entrepreneurial activities.

One measure of the performance of the enterprise is its growth, which is usually measured as sales or employment changes (Delmar, 1997). Research shows that the growth orientation of entrepreneurs is very significant for a company's actual growth. Comparison of growth orientation of entrepreneurs of different genders, can indirectly answer the question about performance entrepreneurs in micro-enterprises. 


\section{RESEARCH METHODOLOGY}

The term: growth orientation is used interchangeably with others, like: growth attitudes, growth aspiration or growth motivation/willingness (McKelvie et al., 2017). The growth willingness is also referred to as growth intentions (Dutta \& Thornhill, 2008). It appears, however, that the growth orientation is reduced only to the objectives, expectations or aspirations chosen by the owner, and does not fully reflect the entrepreneur's growth orientation, which also includes actions and behaviour. In growth orientation, two components should be included: growth intentions and growth behaviour. Literature studies show the influence of the growth intentions of the owner on the growth potential of his/her company (Levie \& Autio, 2013). Dutta and Thornhill (2008) defined growth intentions as: entrepreneurs' goals or aspirations for the growth trajectory she or he would like the venture to follow. By referring to this definition, growth intentions in this research are defined by two indicators: the principal objective chosen by the business owner for the next two years of operation and the planned changes in sales or employment.

Growth behaviour is a result of the entrepreneur's desire for business development, and can manifest itself in many activities, both in terms of innovation, and enhancing the availability and quality of resources (finance, infrastructure), as well as others like increasing the marketing activities etc. The aspect of human resources is overlooked here, because micro-enterprises rarely appreciate it, and therefore this kind of activities are rather absent.

As Coad and Guenther argue in their research, there is a positive relationship between innovation and growth of the firm (2014), however it depends on the growth measure: innovation affects sales growth but not necessarily employment growth (Audretsch et al., 2014). Irrespective of the ambiguous results of innovation - growth of the company relationships, it should be assumed that the introduction of innovation is a manifestation of growth behaviour (McKelvie et al., 2017).

SMEs, and especially micro companies, suffer from a permanent lack of financial resources, which, in the absence of access to the capital market, can negatively affect their growth potential. On the other hand, microfirms, have the opportunity to raise funds from support programs and other alternative sources, like leasing, factoring etc. 
Hence, it can be assumed that the growth behaviour entrepreneur will seek different financing options for the development plans. This assumption is supported by studies that show the relationship between access to finance and growth (see Storey, 2016).

Figure 2 shows the index of growth orientation, which consists of growth intentions and growth behaviors, together with the indicators that define them.

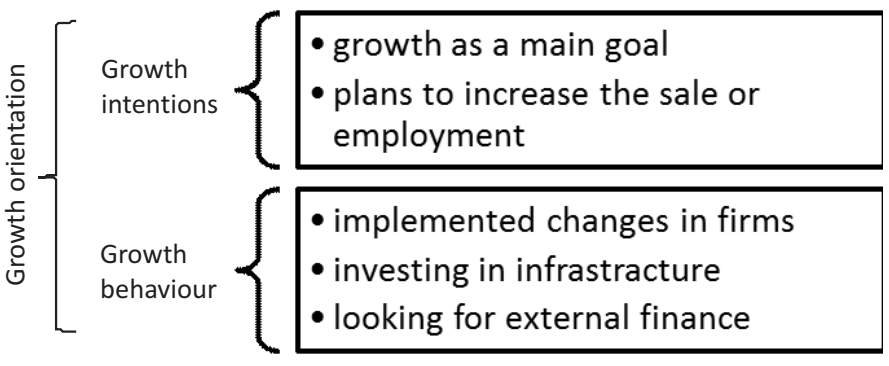

Figure 2. Growth orientation index used in research

Source: own work.

This index was used to explore the growth orientation of entrepreneurs. Each of its indicators is assigned values 1 or 0 as shown in Table 1.

Table 1. The values assigned to each indicator of the growth orientation index

\begin{tabular}{|l|l|l|}
\hline \multicolumn{1}{|c|}{ Indicator } & \multicolumn{1}{|c|}{1} & \multicolumn{1}{c|}{0} \\
\hline $\begin{array}{l}\text { Entrepreneurial } \\
\text { goal }\end{array}$ & Growth & $\begin{array}{l}\text { Other (status quo, decreas- } \\
\text { ing activity, liquidation) }\end{array}$ \\
\hline $\begin{array}{l}\text { Plans for sales } \\
\text { and employment }\end{array}$ & Growth, at least in one case & $\begin{array}{l}\text { Status quo or decrease } \\
\text { in case of both: sales and } \\
\text { employment }\end{array}$ \\
\hline Investments & $\begin{array}{l}\text { Expenditure incurred for the purchase } \\
\text { or modernisation of the last two years } \\
\text { on: buildings and structures, land, } \\
\text { machinery, technical equipment and } \\
\text { tools, and means of transportation }\end{array}$ & No expenditures \\
\hline $\begin{array}{l}\text { Source } \\
\text { of financing }\end{array}$ & $\begin{array}{l}\text { At least two of the following: own } \\
\text { profit, bank loans, leasing, factoring, } \\
\text { and loans from institutions, EU Struc- } \\
\text { tural Funds }\end{array}$ & One or no funding sources \\
\hline Innovations & $\begin{array}{l}\text { Changes in the last two years in: } \\
\text { products, methods of production, and } \\
\text { organisation }\end{array}$ & Lack of changes \\
\hline
\end{tabular}

Source: own work. 
On the basis of the growth orientation assessment of particular indicators the entrepreneurs were classified into three classes: high, medium and low growth orientations. The first group included entrepreneurs for which all growth orientation indicators were 1. For the second group, those who had only three indicators had a value of 1 , assuming that the company's goal was development. Other entrepreneurs were assigned to the low growth orientation category.

\section{RESEARCH ON ENTREPRENEURS IN POMERANIA}

In 2009 a survey among 1,005 micro-entrepreneurs from the Pomerania Province was conducted. These studies were part of a larger project called Pomorskie Obserwatorium Gospodarcze (Pomeranian Economic Observatory), aimed at researching the functioning of Polish micro-enterprises (Dominiak et al., 2013). The companies selected for the research were "young" - operating in the market for no longer than two years. It was also decided that the surveyed companies should be characterised by a high growth potential - therefore, sole traders without employees were excluded, as an assumption was made that such enterprises were established primarily as a workplace for their owners, and not a growth-oriented business. The research method was a direct interview based on a survey questionnaire.

In 2012 , the research was carried out again on the same sample of entrepreneurs, but this time the interviewers reached only 290 of them. The other business people did not agree to the second test or could not be contacted (which may also amount to the cease of activity). The analyses of the answered questionnaires led to reducing the number of interviews. Those entrepreneurs who decreased the employment to zero, between 2009 and 2012 were excluded from the research (87 firms), as the aim of the research was to investigate only firms with a growth potential. Another 18 firms were excluded, as they were too big to be micro ones (employing more than 9 people). Finally, the number of accepted interviews was 157.

There were $29 \%$ of women among the surveyed entrepreneurs, the firms were mainly engaged in service activities ( $80 \%$ or women owned, $86 \%$ of men owned), much less in trade (15\% women and $10 \%$ men), and production ( $4 \%$ women, $5 \%$ men). The average employment in women's firms was 1.86 persons, while the men owned firms employed 
2.56. The owners of both genders felt themselves as entrepreneurial persons equally $-95 \%$.

The growth intentions and growth behaviour, which was decided to be a growth orientation index in this research, was above $55 \%$ in the case of the single indices, and the particular values were listed below:

- growth as a goal $-68 \%$;

- plans for sale or employment growth $-62 \%$;

- investments $-84 \%$;

- $\quad$ more than one source of financing $-55 \%$;

- innovations - 90\%.

Based on the individual indicators of growth orientation, the entrepreneurs were assigned to three groups according to the growth orientation - according to the methodology described above. The entrepreneurs with a high growth orientation accounted for $27 \%$ of the sample tested, the entrepreneurs with an average growth orientation of $24 \%$, and those with a low one almost half $-48 \%$. The growth orientation index gender analysis of the owner points to a lower share of women in the high and middle-income group (22\% and $24 \%$ ) compared to men ( $29 \%$ and $26 \%)$. Thus, women were more characterised by a low growth orientation (54\% versus $45 \%$ ) (Table 2 ).

Tabela 2. Growth orientation based on the owners' gender

\begin{tabular}{|l|c|c|c|c|}
\hline \multicolumn{1}{|c|}{ Growth orientation } & High & Medium & Low & Sum \\
\hline Women & $22 \%$ & $24 \%$ & $54 \%$ & $100 \%$ \\
\hline Men & $29 \%$ & $26 \%$ & $45 \%$ & $100 \%$ \\
\hline All entrepreneurs & $27 \%$ & $25 \%$ & $48 \%$ & $100 \%$ \\
\hline
\end{tabular}

Source: own computation.

The lower value of the growth orientation index for women is the result of the less frequent selection of growth as the main goal $(65 \% \mathrm{~W}$, $69 \% \mathrm{M})$. This result does not show big differences between women and men, and is consistent with the conclusions of the research carried out by the Polish Agency for Enterprise Development, in which the growth plans of women running their own companies were not significantly different from the plans of men (Balcerzak-Paradowska, 2011, p. 76). Also plans for employment growth for women turned out to be lower (23\%) than these for men (43\%). On the other hand, more women planned to increase sales $(52 \% \mathrm{~W}, 43 \% \mathrm{M})$. The more recent studies of 
entrepreneurs in Poland, conducted as part of Global Entrepreneurship Monitor, also show a difference in aspirations for increasing employment: $81 \%$ of women and $87 \%$ of men running their companies for no longer than 3.5 years declare employment growth over the next five years (Zadura-Lichota, 2014). However, the number of owners planning to growth the employment was higher in GEM research.

The second indicator that influenced the lower growth orientation of women is clearly lower investment activity $(74 \% \mathrm{~W}, 89 \% \mathrm{M})$.

The other two indicators: funding sources and innovation activities, did not show large differences between genders. In this first case, the share of women benefiting from at least two sources of funding was larger by 2 percentage points than men and was $57 \%$. In the case of innovation, the relationship was reversed, the share of women making changes in the company was $89 \%$ and was two percentage points lower than that of men.

\section{CONCLUSIONS AND DISCUSSION}

The comparative studies on the entrepreneurs of both genders have been conducted for many years. The studies described in the literature and the conclusions drawn from them, although often pointing to differences in the functioning of businesses run by women and men, are often ambiguous, and the differences themselves are often exaggerated. These ambiguities also apply to the performance of firms owned by women and men.

The growth orientation index does not give a clear answer to the performance of women versus men entrepreneurs. It points to a lower percentage of female entrepreneurs with a high level of growth orientation, compared to the percentage of men, but the difference is only two percentage points. On the other hand, the share of low growth oriented women (33\%) was lower than those of men (45\%). Finally, almost half (48\%) of the surveyed women were classified as medium growth oriented, with $35 \%$ of the men. And this difference, in favour of women is 10 percentage points.

Looking at this research output the conclusion about the ambiguity could also be applied. It is difficult to draw clear conclusions from the small differences between the share of women and men with high growth orientation. Ahl (2006) rightly notes that the interpretation of such 
results depends to a large extent on the attitude of the researchers. If they believe in the presence of differences, they will be highlighting even slight variations as confirming their hypotheses. Ahl called it making a mountain out of a molehill strategy. If, however, they are convinced of the lack of differences, they will diminish the value of such deviations.

While research micro and small firms, there are always some limitations, one of them is heterogeneity of the researched firms. In the described study, this problem was eliminated, all firms were micro ones, not older than 7 years and finely operated mostly in the same industry. As a result, the owner's gender was the main factor differentiating companies. If the gender dimension is to be taken into account in research, it has to be conducted among sole traders. Conducting large-scale research among such entrepreneurs in Poland is not easy. The entrepreneurs are reluctant to answer questions, especially those concerning the financial aspects of their companies (and, as the discussions with researchers from other countries show, this problem is present not only in Poland). This should be taken into consideration when planning the study.

The research output is valid only for the Polish reality. Studies conducted in culturally different countries cannot be freely used for comparison purposes. This applies to research on entrepreneurship, and in particular women's entrepreneurship. Various institutional conditions, both formal (barriers, support, etc.) and informal - i.a. cultural - influence different behaviours of women in business. It must be remembered that the opinions functioning in everyday discourse, building the image of Polish women as heroic mothers, cannot be ruled out. This stereotype is rooted in the consciousness of the Polish society and resulting from historical conditions dating back to the period of 19 th century uprisings, when women were left by the men involved in the defence of Polish statehood. It can also affect the sense of self-efficacy, approach to risk, or perseverance.

\section{REFERENCES}

Ahl, H. (2002). The Making of the Female Entrepreneur. Doctoral Thesis. Jonkoping International Business School.

Ahl, H. (2006). Why research on women entrepreneurs needs new directions. Entrepreneurship Thery and Practice, 30(5), 595-621. 
Audretsch, D.B., Coad, A. \& Segarra, A. (2014). Firm growth and innovation. Small Business Economics, 43(4), 743

Balcerzak-Paradowska, B. (2011). Przedsiębiorczość kobiet w Polsce. Warszawa: PARP.

Calcagnini, G., Giombini, G. \& Lenti, E. (2015). Gender differences in bank loan access: An empirical analysis. Italian Economic Journal, 1(2), 193-217.

Coad, A. \& Guenther, C. (2014). Processes of firm growth and diversification: Theory and evidence. Small Business Economics, 43(4), 857-871.

Delmar, F. (1997). Measuring growth: Methodological considerations and empirical results. In: R. Donckels, A. Miettinen, Entrepreneurship and SME Research: On its Way to the Next Millennium. Aldershot, England: Ashgate, 199-216.

Dominiak, P., Wasilczuk, J.E., Zięba, K., Daszkiewicz, N. \& Sobiechowska-Ziegert, A. (2013). Sektor MSP na Pomorzu w warunkach spowolnienia tempa wzrostu gospodarczego. Gdańsk: Agencja Rozwoju Pomorza.

Dutta, D.K. \& Thornhill, S. (2008). The evolution of growth intentions: Toward a cognition-based model. Journal of Business Venturing, 23, 307-322.

European Commission (2014). Statistical Data on Women Entrepreneurship in Europe. http://ec.europa.eu/growth/tools-databases/newsroom/cf/itemdetail. cfm?item_id=7992 (access: 20.05.2016).

European Commission (2016). Justice. http://ec.europa.eu/justice/gender-equality/ gender-pay-gap/index_en.htm (access: 25.03.2016).

Fischer, E., Reuber, R. \& Dyke, L.S. (1993). A theoretical overview and extension of research on sex, gender, and entrepreneurship. Journal of Business Venturing, 151-168.

Gawrycka, M., Wasilczuk, J.E. \& Zwiech, P. (2007). Szklany sufit i ruchome schody. Kobieta na rynku pracy. Warszawa: CeDeWu.

Glinka, B. (2008). Kulturowe uwarunkowania przedsiębiorczości w Polsce. Warszawa: PWE.

Jennings, J.E. \& Brush, C.G. (2013). Research on women entrepreneurs: Challenges to (and from) the browder entrepreneurship literature? The Academy of Management Annals, 7(1), 661-713.

Jones, G. \& Wadhwani, D. (2006). Entrepreneurship and Business History: Renewing the Research Agenda. Working paper.

Kelley, D., Singer, S. \& Herrington, M. (2016). Global Entrepreneruship Monitor 2015/2016. GERA.

Lee, I.H. \& Marvel, M.R. (2014). Revisiting the entrepreneur gender-performance relationship: a firm perspective. Small Business Economics, 42(4), 769-786.

Levie, J. \& Autio, E. (2013). Growth and Growth Intentions: A Meta-analysis of Existing Evidence (ERC White Papers; No. 1). Enterprise Research Centre. 
Marlow, S. \& Patton, D. (2007) All credit to men? Entrepreneurship, finance, and gender. Entrepreneurship Theory and Practice, 29(6), 717-735.

McKelvie, A., Brattström, A. \& Wennberg K. (2017). How Young Firms Achieve Growth: Reconciling the Roles of Growth Motivation and Innovative Activities. Small Business Economics, 49(2), 273-293.

Muravyev, A., Talavera, O. \& Schafer, D. (2009). Entrepreneurs' gender and financial constraints: Evidence from international data. Journal of Comparative Economics, 37, 2, 270-286.

Poggesi, S., Mari, M. \& De Vita, L. (2015). What's new in female entrepreneurship research? Answers from the literature. International Entrepreneurship and Management Journal, 12(3), 735-764.

Sabarwal, S. \& Terrell, K. (2008). Does Gender Matter for Firm Performance? Evidence from Eastern Europe and Central Asia. Policy Research Working Paper 4704: The World Bank. Poverty Reduction and Economic Management Network. Gender and Development Group.

Storey, D. (2016), Understanding the Small Business Sector. Routledge.

Survey of Business Owners (2016). Census. https://www.census.gov/econ/sbo/ historical.html (access: 17.03.2017).

United States Department of Commerce (1979). The Bottom Line: Unequal Enterprise in America. Washington: United States Department of Commerce.

Wasilczuk, J.E. (2005). Wzrost matych $i$ średnich przedsiębiorstw: aspekty teoretyczne $i$ badania empiryczne. Gdańsk: Politechnika Gdańska.

Wasilczuk, J.E. (2015). Płeć a motywacje przedsiębiorcze oraz podejmowane przez mikroprzedsiębiorców decyzje zarządcze. Problemy Zarzadzania, 4(56), 115-130.

Women, Business and the Law 2016 (2016). Getting to Equal Report.

Zadura-Lichota, P. (2014). Wyniki badania populacji dorosłych - APS. In: Global Entrepreneurship Monitor Polska. Raport z badań 2013. Warszawa: Polska Agencja Rozwoju Przedsiębiorczości, 17-43. 


\section{ORIENTACJA WZROSTOWA WKAŚCICIELI MIKROPRZEDSIĘBIORSTW WOJEWÓDZTWA POMORSKIEGO W ZALEŻNOŚCI OD PKCI}

Tło badań. Mimo że badania nad przedsiębiorczością kobiet prowadzone są od wielu lat, wciąż brakuje jasnych odpowiedzi na pytania o różnice między przedsiębiorcami obu płci. Jednym z nierozwiązanych problemów są wyniki osiagane przez kobiety przedsiębiorczynie.

Cel badań. Celem artykułu jest zbadanie orientacji rozwojowej mikroprzedsiębiorstw działających w regionie pomorskim w Polsce oraz określenie jej poziomu w zależności od płci właściciela.

Metodologia. Opracowano indeks orientacji na rozwój przedsiębiorców. Indeks ten, będący wyznacznikiem potencjału wzrostu firmy, opierał się na pięciu wskaźnikach: celach i planach przedsiębiorcy, działaniach innowacyjnych, inwestycjach oraz aktywności w poszukiwaniu źródeł finansowania. Dane zostały zebrane przy wykorzystaniu wywiadu kwestionariuszowego, przeprowadzonego bezpośrednio wśród właścicieli mikrofirm z Pomorza w 2009 i 2012 roku.

Kluczowe wnioski. Analiza orientacji wzrostowej kobiet i mężczyzn wykazała, że kobiety prezentują niższą jej wartość.

Słowa kluczowe: przedsiębiorczość kobiet, orientacja wzrostowa. 